\title{
ANALISIS MUTU KERUPUK TALAS DENGAN PERLAKUAN BAHAN DASAR DAN PENAMBAHAN NaHCO3
}

\section{QUALITY ANALYSIS OF TARO CHIPS WITH TREATMENT OF BASIC MATERIALS AND NaHCO3 ADDITION}

\author{
Selvia Oktaviani \\ 1) Program Studi Teknologi Pertanian Fakultas Pertanian \\ Universitas Dehasen Bengkulu
}

\begin{abstract}
ABSTRAK
Talas merupakan salah satu sumber karbohidrat yang mempunyai potensi tinggi untuk dikembangkan menjadi produk pangan. Telah dilakukan penelitian yang bertujuan untuk menganalisis sifat kimia, fisik dan organoleptik kerupuk talas dengan perlakuan bahan dasar dan penambahan $\mathrm{NaHCO}_{3}$, serta untuk mendapatkan jumlah konsentrasi penambahan bahan dasar dan $\mathrm{NaHCO}_{3}$ yang tepat dalam pembuatan kerupuk talas terhadap sifat organoleptik. Penelitian dilakukan 2 tahap, yaitu pembuatan kerupuk talas dengan perlakuan bahan baku dan penambahan natrium bikarbonat $\mathrm{NaHCO}_{3}$ dengan variasi konsentrasi $0,4 \%, 0,8$ dan 1,2\% serta tahap analisis. Analisis yang dilakukan meliputi kadar air, volume pengembangan dan uji sensoris untuk menentukan tingkat kesukaan konsumen terhadap kerupuk talas berdasarkan parameter warna, rasa dan kerenyahan.Hasil penelitian menunjukkan bahwa kadar air tertinggi pada sampel kerupuk talas adalah dengan bahan dasar tepung talas $150 \mathrm{~g}+$ tapioka $50 \mathrm{~g}$, konsentrasi $0,4 \%$ yaitu sebesar $11,342 \%$. Selanjutnya, volume pengembangan kerupuk talas tertinggi terdapat pada perlakuan bahan dasar tepung talas $50 \mathrm{~g}+$ tapioka $150 \mathrm{~g}$ dengan konsentrasi $1,2 \%$ yaitu sebesar $650,233 \%$ serta nilai tekstur tertinggi terdapat pada perlakuan bahan dasar tepung talas $50 \mathrm{~g}+$ tapioka $150 \mathrm{~g}$ dengan konsentrasi $1,2 \%$ yaitu sebesar 63,05\%. Hasil uji sensoris menunjukkan bahwa kerupuk talas yang paling disukai oleh panelis adalah kerupuk dengan bahan dasar tepung talas $150 \mathrm{~g}+$ tapioka $50 \mathrm{~g}$, konsentrasi 0,4\% yaitu sebesar 1,60 dengan kategori sangat menarik, untuk parameter warna, kerupuk talas dengan bahan dasar tepung talas $150 \mathrm{~g}+$ tapioka $50 \mathrm{~g}$, konsentrasi $0,4 \%$ yaitu sebesar 1,75 dengan kategori sangat enak, untuk parameter rasa dan kerupuk talas dengan bahan dasar tepung talas $150 \mathrm{~g}+$ tapioka $50 \mathrm{~g}$, konsentrasi 1,2\% yaitu sebesar 1,25 dengat kategori sangat renyah, untuk parameter tekstur.
\end{abstract}

Kata kunci : talas, kerupuk talas, natrium bikarbonat $\left(\mathrm{NaHCO}_{3}\right)$

\section{ABSTRACT}

Taro is one source of carbohydrates that has high potential to be developed into food products. The aim of this research is to analyzing the chemical, physical and organoleptic properties of taro chips by treating the base material and adding $\mathrm{NaHCO}$, as well as obtaining the right amount of concentration of adding basic ingredients and NaHCO3 in making taro chips on organoleptic properties. The research was carried out in two stages, namely making taro chips with the treatment of raw materials and adding sodium bicarbonate $\mathrm{NaHCO} 3$ with variations in concentrations of $0.4 \%, 0.8$ and $1.2 \%$ and the analysis stage. Analysis carried out included water content, volume of development and sensory testing to determine the level of consumer preference for taro chips based on color, 
taste and crisp parameters. The results showed that the highest moisture content in taro chips samples was $150 \mathrm{gr}+$ tapioca 50 basic ingredients. gr, concentration $0.4 \%$ which is equal to $11.334 \%$. Furthermore, the highest volume of taro chips development is found in the treatment of basic ingredients of $50 \mathrm{~g}$ taro flour $+150 \mathrm{~g}$ tapioca with a concentration of $1.2 \%$, amounting to $650.233 \%$ and the highest texture value found in the treatment of $50 \mathrm{~g}$ taro flour $+150 \mathrm{~g}$ tapioca with concentration 1, 2\% which is equal to 63.05\%. Sensory test results showed that taro chips were most preferred by panelists were chips with the basic ingredients of $150 \mathrm{~g}$ taro flour $+50 \mathrm{~g}$ tapioca, concentrations of $0.4 \%$ which amounted to 1.60 with a very interesting category for color parameters, taro chips with basic ingredients $150 \mathrm{~g}$ taro flour $+50 \mathrm{~g}$ tapioca, $0.4 \%$ concentration which is equal to 1.75 with very tasty category, for flavor parameters and taro chips with basic ingredients of $150 \mathrm{~g}$ taro flour +50 $g$ tapioca flour, concentration 1.2\% which is equal to 1,25 categories of very crunchy, for texture parameters.

Keyword : taro, taro chips, natrium bikarbonat $\left(\mathrm{NaHCO}_{3}\right)$

\section{PENDAHULUAN}

Talas memiliki kandungan nutrisi dengan kalori yang tinggi namun rendah gula. Disamping itu, talas juga mempunyai keunggulan lain, yaitu kaya akan Hyaluronic Acid (HA), substansi yang diproduksi secara alami oleh tubuh yang jumlahnya berlimpah ketika masih muda. Hyaluronic acid sangat berperan dalam kesehatan sendi, penglihatan, jaringan penghubung (connective tissue), mempercepat proses penyembuhan luka, dan sangat berperan dalam pembentukan kolagen. Selain itu umbi segar merupakan sumber calsium dan kalori yang tinggi, tetapi kandungan karbohidratnya rendah sehingga dapat dikonsumsi sebagai makanan diet penderita diabetes.

Saat ini, kebanyakan masyarakat mengkonsumsi talas dalam bentuk olahan yang sangat sederhana seperti direbus atau digoreng. Oleh karena itu, pengembangan produk olahan talas masih punya potensi luas salah satunya pengolahan kerupuk talas. Pada umumnya produsen kerupuk masih banyak menggunakan bahan pengembang adonan kerupuk yang bersifat sintetik, seperti formalin dan boraks. Memang bahan-bahan ini memiliki kelebihan yaitu pekat, lebih stabil, dan lebih murah. Tetapi, bahan ini juga memiliki kelemahan yaitu sering terjadi ketidakseimbangan proses sehingga mengandung zat-zat yang berbahaya bagi kesehatan. Oleh karena itu, Badan Pengawasan Obat dan Makanan (BPOM) sudah melarang penggunaan bahan tersebut (Matz dan Matz, 1978 dalam Marliyati 1992). Bahan pengembang adonan yang sering dipakai menggunakan bahan-bahan kimia yang dapat menghasilkan gas $\mathrm{CO}_{2}$. Sumber gas $\mathrm{CO}_{2}$ yang popular penggunaannya pada produk makanan adalah Natrium 
bikarbonat $\left(\mathrm{NaHCO}_{3}\right)$ (Matz dan Matz, 1978 dalam Marliyati 1992).

Dalam proses pembuatan kerupuk talas, talas terlebih dahulu dijadikan tepung talas. Tepung talas merupakan hasil pengolahan bahan umbi talas dengan cara penggilingan atau penepungan. Tepung talas memiliki kadar air yang rendah, dibandingkan dengan umbi talas dengan cara pengukusan. Kadar pati dan kadar amilosa yang dihasilkan dari tepung talas juga lebih rendah dari kadar pati dan kadar amilosa yang berasal dari umbi talas halus yang diolah melaui pengukusan. Hal ini disebabkan karena pati yang berasal dari umbi diperoleh dari ekstraksi langsung dari umbi talas. Sehingga dalam proses pembuatan makanan akan diperoleh pati yang lebih murni. Kadar air yang rendah akan berpengaruh terhadap keawetan makanan yang terbuat dari tepung seperti kerupuk dan juga mempermudah dalam proses pengeringan. Cara yang paling umum untuk dilakukan untuk menurunkan kadar air adalah dengan pengeringan, baik dengan penjemuran atau dengan alat pengering biasa (Widowati, 2005).

Oleh karena itu perlu penggunaan bahan pengembang yang tidak membahayakan kesehatan dan mudah didapat, serta aplikasi tepung talas pada kerupuk, sehingga dapat diterima konsumen dalam hal sifat kimia, fisika dan organoleptik yang meliputi warna, rasa dan kerenyahan.

Penelitian ini bertujuan untuk mengkarakterisasi sifat fisik, kimia dan sensoris kerupuk talas dengan perlakuan komposisi bahan dasar dan konsentrasi penambahan $\mathrm{NaHCO}_{3}$.

\section{METODOLOGI}

\section{Bahan dan Alat}

Bahan yang digunakan dalam penelitian ini yaitu talas jepang (satoimo), tepung tapioka, Natrium bikarbonat $\left(\mathrm{NaHCO}_{3}\right)$, garam, ketumbar, bawang merah, bawang putih, minyak goreng. Adapun alat yang digunakan pada penelitian ini adalah timbangan, pisau, talenan, tampah, baskom sedang, dandang, wajan, sendok goreng, sendok saringan, kompor, alat penumbuk, roller, plastik, dan gelas ukur, dan alat analisis.

\section{Metode}

Penelitian dilaksanakan dalam dua tahap, yaitu tahap pengolahan tepung talas dan tahap pengolahan kerupuk talas dengan variasi perlakuan komposisi bahan baku yaitu komposisi tepung talas dan tepung tapioka (150:50 dan 50:150), serta variasi perlakuan penambahan natrium bikarbonat $0,4 \%, 0,8$ dan 1,2\%. Sampel kerupul talas hasil perlakuan, dianalisis fisik (volume pengembangan dan tekstur), kimia (kadar air) dan uji sensoris untuk 
menganalisis tingkat kesukaan 20 orang panelis terlatih berdasarkan parameter warna, rasa dan kerenyahan.

\section{HASIL DAN PEMBAHASAN}

\section{Analisis Rendemen Tepung Talas}

Hasil pengukuran rendemen pengolahan kerupuk talas, diperoleh hasil sebesar 25\%. Menurut Hanafiah (1993), pengolahan tepung yang baik akan menghasilkan rendemen minimal sebesar $50 \%$. Hal ini tidak sesuai dengan hasil penelitian ini. Kecilnya rendemen pengolahan tepung talas dalam penelitian ini diduga disebabkan karena adanya kehilangan bobot pada saat pengayakan karena proses penggilingan yang kurang optimal sehingga ukuran partikel tepung yang dihasilkan masih cukup besar.

\section{Analisis Kadar Air Kerupuk Talas}

Hasil rerata analisis kadar air kerupuk talas dengan perlakuan bahan baku tepung talas dan tepung tapioka dengan konsentrasi Natrium bikarbonat sebanyak $0,4 \%, 0,8 \%$ dan $1,2 \%$ dapat dilihat pada Tabel 1.
Tabel 1 menunjukkan bahwa semakin tinggi konsentrasi natrium bikarbonat maka kadar air kerupuk talas juga semakin tinggi. Baik pada perlakuan bahan dasar tepung talas $150 \mathrm{gr}+$ tapioka 50 gr maupun dengan perlakuan bahan dasar tepung talas $50 \mathrm{gr}+$ tapioka $150 \mathrm{gr}$ konsentrasi natrium bikarbonat $0,4 \%$, $0,8 \%$ maupun $1,2 \%$. Namun jika dibandingkan antara perlakuan bahan dasar tepung talas $150 \mathrm{gr}+$ tapioka $50 \mathrm{gr}$ dengan tepung talas $50 \mathrm{gr}+$ tapioka 150 gr, kadar air tepung talas $150 \mathrm{gr}+$ tapioka 50 gr lebih tinggi. Hal ini disebabkan karena porsi tepung talas lebih tinggi dibandingkan tepung tapioka, karena kandungan protein pada tepung talas lebih tinggi yaitu 3,38 gram. Sedangkan protein tepung tapioka adalah sebesar 0,5 gram. Kadar air pada suatu produk erat hubungannya dengan peningkatan air oleh protein, yaitu peningkatan air yang tinggi akan mengurangi pelepasan air selama pemasakan, dengan demikian kadar air produk akan tinggi.

Tabel 1. Rerata Analisa Kadar Air Kerupuk Talas (\%)

\begin{tabular}{ccc}
\hline$\%$ & \multicolumn{2}{c}{ Perlakuan Bahan Dasar } \\
\cline { 2 - 3 } $\mathrm{NaHCO}_{3}$ & $\begin{array}{c}\text { Tepung Talas 150 gr }+ \\
\text { Tapioka 50 gr }\end{array}$ & $\begin{array}{c}\text { Tepung Talas 50 gr }+ \\
\text { Tapioka 150 gr }\end{array}$ \\
\hline $0,4 \%$ & $11,342^{\mathrm{a}}$ & $10,739^{\mathrm{ab}}$ \\
$0,8 \%$ & $10,775^{\mathrm{ab}}$ & $9,725^{\mathrm{bc}}$ \\
$1,2 \%$ & $10,181^{\mathrm{bc}}$ & $9,402^{\mathrm{c}}$ \\
\hline
\end{tabular}

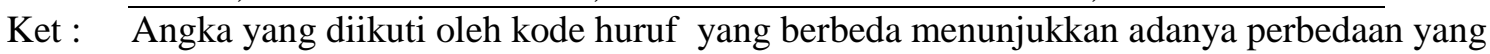
nyata pada taraf signifikansi 5\%, (pada kolom yang sama). 
Hasil analisis menunjukkan bahwa kadar air kerupuk talas berkisar antara 9 $11 \%$. Hal ini telah sesuai dengan standar mutu SNI 01-2713-2004, yang menetapkan kadar air produk kerupuk maksimal sebesar 12\%. Penambahan konsentrasi natrium bikarbonat dan bahan baku tepung talas dan tepung tapioka berpengaruh terhadap kadar air kerupuk talas yaitu semakin tinggi penambahan konsentrasi natrium bikarbonat maka semakin rendah kadar air kerupuk talas. Menurut Edward, (1997) mengatakan bahwa kandungan air pada bahan pangan akan mempengaruhi mutu dari pangan tersebut. Semakin tinggi kadar air akan semakin lembek pangan tersebut, begitu juga kalau kadar airnya rendah biasanya semakin keras juga pangan tersebut. Kerupuk talas memiliki kandungan natrium bikarbonat dan pati dalam kerupuk talas yang berpengaruh karena adanya amilopektin yang bersifat memacu terjadinya pengembangan sehingga kerupuk talas dengan kandungan amilopektin yang tinggi akan bersifat ringan, garing mudah patah karena memiliki kadar air yang rendah.

\section{Analisis Volume Pengembangan} Kerupuk Talas

\footnotetext{
Hasil analisis volume pengembangan kerupuk talas dengan
}

perlakuan bahan baku tepung talas dan tepung tapioka dengan konsentrasi Natrium bikarbonat sebanyak $0,4 \%, 0,8 \%$ dan 1,2\% dapat dilihat pada tabel 2 .

Volume pengembangan tertinggi terdapat pada perlakuan bahan dasar tepung talas $50 \mathrm{gr}+$ tapioka $150 \mathrm{gr}$ dengan konsentrasi 1,2\% yaitu sebesar $650,233 \%$, sedangkan volume pengembangan terendah adalah perlakuan bahan dasar tepung talas $150 \mathrm{gr}+$ tapioka 50 gr dengan konsentrasi $0,4 \%$ yaitu sebesar 486,133\%. Penambahan konsentrasi natrium bikarbonat dan perlakuan bahan dasar berpengaruh terhadap volume pengembangan yaitu semakin tinggi penambahan konsentrasi natrium bikarbonat maka akan semakin besar volume pengembangan kerupuk talas yang dihasilkan. Menurut Wijaya (2002), Natrium bikarbonat dalam pembuatan kerupuk talas berfungsi sebagai pengembangan adonan kerupuk pada saat penggorengan. Natrium bikarbonat mudah larut dalam air pada suhu rendah dan dalam kerupuk talas akan bereaksi dengan protein maupun ion-ion dari bahan-bahan yang lain, sehingga akan menghasilkan gas yang akan menyababkan kerupuk talas menjadi mengembang dan berpori-pori. 
Tabel 2. Rerata Analisis Volume Pengembang Kerupuk Talas (\%)

\begin{tabular}{ccc}
\hline$\%$ & \multicolumn{2}{c}{ Perlakuan Bahan Dasar } \\
\cline { 2 - 3 } $\mathrm{NaHCO}_{3}$ & $\begin{array}{c}\text { Tepung Talas 150 gr }+ \\
\text { Tapioka 50 gr }\end{array}$ & $\begin{array}{c}\text { Tepung Talas 50 gr }+ \\
\text { Tapioka 150 gr }\end{array}$ \\
\hline $0,4 \%$ & $486,133^{\mathrm{c}}$ & $505,733^{\mathrm{c}}$ \\
$0,8 \%$ & $544,567^{\mathrm{bc}}$ & $561,233^{\mathrm{bc}}$ \\
$1,2 \%$ & $612,400^{\mathrm{b}}$ & $650,233^{\mathrm{a}}$ \\
\hline
\end{tabular}

Ket : Angka yang diikuti oleh kode huruf yang berbeda menunjukkan adanya perbedaan yang nyata pada taraf signifikansi 5\%, (pada kolom yang sama).

Menurut Virgit (2004), selain natrium bikarbonat volume pengembangan dipengaruhi oleh kandungan karbohidrat dan protein dari bahan pembuatnya. Tepung talas mengandung karbohidrat sebesar 1,33 gram dan protein 2,38 gram. Sedangkan tepung tapioka mengandung karbohidrat sebesar 88,69 gram dan protein 0,19 gram. Untuk kandungan air tepung talas 69,2 gram dan tepung tapioka adalah 62.50 gram Pengembangan kerupuk talas di pengaruhi oleh protein, protein yang mengalami hidrolisis mempunyai gugus reaktif yang akan mengikat air dan akan mengalami koagulasi kemudian masuk ke sela-sela granula pati. Selain itu protein berikatan dengan karbohidrat sehingga granula berisi protein dan mengakibatkan kemampuan granula pati menyerap air menurun. Jika air yang menguap tidak mampu mendorong granula pati mengembang sehingga kerupuk menjadi tidak mengembang dan mempunyai tekstur yang keras. Protein yang terdenaturasi berakibat kelarutannya rendah sehingga amilopektin mampu mengikat air secara optimal. Ronggarongga granula yang tidak berisi padatan protein, pada saat penggorengan air yang terikat dengan amilopektin memuai mendesak gel pati pengembang sampai terbentuk struktur kerupuk yang renyah.

Jenis kerupuk memiliki volume pengembangan yang berbeda, namun pada umumnya standar volume pengembangan adalah antara $300 \%$ sampai dengan $700 \%$. Jika dibandingkan antara volume pengembangan kerupuk talas dengan penelitian yang lain maka terjadi perbedaan. Semakin besar penambahan Natrium bikarbonat maka volume pengembangan kerupuk juga semakin besar. Sedangkan menurut Lavlinesia (1995), semakin tinngi kandungan lemak yang terdapat pada bahan pembuatan kerupuk maka semakin rendah volume pengembangan, karena adanya lemak dalam adonan dapat mengganggu proses gelatinisasi karena lemak membentuk lapisan lemak pada permukaan granula 
yang menyebabkan penetrasi air terganggu.

\section{Analisis Tekstur Kerupuk Talas}

Hasil analisis tekstur kerupuk talas dengan perlakuan bahan baku tepung talas dan tepung tapioka dengan konsentrasi Natrium bikarbonat sebanyak $0,4 \%, 0,8 \%$ dan 1,2\% dapat dilihat pada Tabel 3 .

Hasil analisis menunjukkan bahwa semakin tinggi konsentrasi natrium bikarbonat maka maka semakin tinggi nilai tekstur yang dihasilkan, dalam artian tekstur dari kerupuk talas semakin renyah. Menurut Virgit (2004), hal ini dipengaruhi oleh kandungan karbohidrat, protein dan kandungan air dari bahan pembuatnya. Tepung talas mengandung karbohidrat sebesar 1,33 gram dan protein 2,38 gram, sedangkan tepung tapioka mengandung karbohidrat sebesar 88,69 gram dan

protein 0,19 gram. Untuk kandungan air tepung talas 69,2 gram dan tepung tapioka adalah 62.50 gram sehingga kerupuk yang dihasilkan semakin renyah atau keras.

Rerata tekstur kerupuk talas tertinggi yaitu terdapat perlakuan penambahan bahan baku tepung talas dengan konsentrasi njatrium bikarbonat $1,2 \%$ yaitu sebesar $63,05 \mathrm{~g} / \mathrm{mm}^{2}$. Tekstur kerupuk meningkat sejalan dengan meningkatnya volume pengembangan kerupuk. Hasil uji volume pengembangan kerupuk dengan kandungan amilopektin yang lebih tinggi akan memiliki volume pengembangan yang tinggi, karena pada saat proses pemanasan akan terjadi proses gelatinasi dan akan terbentuk struktur yang elastis yang kemudian dapat mengembang pada tahap penggorengan sehingga kerupuk dengan volume pengembangan yang tinggi akan memiliki kerenyahan yang tinggi.

\begin{tabular}{ccc}
\multicolumn{3}{c}{ Tabel 3. Rerata Analisis Tekstur Kerupuk Talas $\left(\mathbf{g} / \mathbf{m m}^{2}\right)$} \\
\hline$\%$ & \multicolumn{2}{c}{ Perlakuan Bahan Dasar } \\
\cline { 2 - 3 } $\mathrm{NaHCO}_{3}$ & $\begin{array}{c}\text { Tepung Talas 150 gr }+ \\
\text { Tapioka 50 gr }\end{array}$ & $\begin{array}{c}\text { Tepung Talas 50 gr }+ \\
\text { Tapioka 150 gr }\end{array}$ \\
\hline $0,4 \%$ & $58,73^{\mathrm{c}}$ & $60,11^{\mathrm{bc}}$ \\
$0,8 \%$ & $60,78^{\mathrm{b}}$ & $61,22^{\mathrm{b}}$ \\
$1,2 \%$ & $61,90^{\mathrm{ab}}$ & $63,05^{\mathrm{a}}$ \\
\hline
\end{tabular}

Ket : Angka yang diikuti oleh kode huruf yang berbeda menunjukkan adanya perbedaan yang nyata pada taraf signifikansi 5\%, (pada kolom yang sama) 


\section{Uji Organoleptik Warna Kerupuk} Talas

Hasil analisis uji organoleptik warna kerupuk talas dengan perlakuan bahan tepung talas dan tepung tapioka dengan konsentrasi natrium bikarbonat sebanyak $\quad 0,4 \%, \quad 0,8 \%$ dan $1,2 \%$ ditunjukkan dalam Tabel 4.

Uji organoleptik oleh 20 orang panelis terlatih untuk parameter warna menunjukkan bahwa warna kerupuk talas yang paling disukai adalah dengan bahan dasar tepung talas $150 \mathrm{gr}+$ tapioka $50 \mathrm{gr}$, konsentrasi $0,4 \%$ yaitu sebesar 1,60 dengat kategori menarik. Penilaian terhadap warna kerupuk talas dengan perlakuan bahan baku tepung talas dan tepung tapioka dengan konsentrasi natrium bikarbonat sebanyak $0,4 \%, 0,8 \%$ dan $1,2 \%$ mengalami perbedaan, hal ini dapat disebabkan oleh persentase tepung talas dan tepung tapioka yang tinggi. Semakin banyak persentase tepung tapioka maka semakin kekuningan warna kerupuk talas tersebut. Juga dengan proses penggorengan akan mengubah warna dari kerupuk talas tersebut menjadi kekuningan. Menurut Murdijati dkk (2005), makanan yang digoreng mempunyai warna yang khas dan diterima oleh hampir semua orang.

\section{Uji Organoleptik Rasa Kerupuk Talas}

Hasil analisis uji organoleptik rasa kerupuk talas dengan perlakuan bahan baku tepung talas dan tepung tapioka dengan konsentrasi natrium bikarbonat sebanyak $0,4 \%, \quad 0,8 \%$ dan $1,2 \%$ ditampilkan pada Tabel 5.

Tabel 4. Rerata Nilai Tingkat Kesukaan Warna Kerupuk Talas

\begin{tabular}{ccc}
\hline$\%$ & \multicolumn{2}{c}{ Perlakuan Bahan Dasar } \\
\cline { 2 - 3 } $\mathrm{NaHCO}_{3}$ & $\begin{array}{c}\text { Tepung Talas 150 gr }+ \\
\text { Tapioka 50 gr }\end{array}$ & $\begin{array}{c}\text { Tepung Talas 50 gr }+ \\
\text { Tapioka 150 gr }\end{array}$ \\
\hline $0,4 \%$ & $1,60^{\mathrm{c}}$ & $2,05^{\mathrm{bc}}$ \\
$0,8 \%$ & $2,45^{\mathrm{abc}}$ & $2,15^{\mathrm{abc}}$ \\
$1,2 \%$ & $2,80^{\mathrm{a}}$ & $2,75^{\mathrm{ab}}$ \\
\hline
\end{tabular}

Ket : Angka yang diikuti oleh kode huruf yang berbeda menunjukkan adanya perbedaan yang nyata pada taraf signifikansi 5\%, (pada kolom yang sama) Ket Skala : 1= sangat menarik; $2=$ menarik; $3=$ netral; 4 = tidak menarik; 5 = sangat tidak menarik (pada kolom yang sama) 
Tabel 5. Rerata Nilai Tingkat Kesukaan Rasa Kerupuk Talas

\begin{tabular}{ccc}
\hline$\%$ & \multicolumn{2}{c}{ Perlakuan Bahan Dasar } \\
\cline { 2 - 3 } $\mathrm{NaHCO}_{3}$ & $\begin{array}{c}\text { Tepung Talas 150 gr }+ \\
\text { Tapioka 50 gr }\end{array}$ & $\begin{array}{c}\text { Tepung Talas 50 gr }+ \\
\text { Tapioka 150 gr }\end{array}$ \\
\hline $0,4 \%$ & $1.75^{\mathrm{c}}$ & $1.80^{\mathrm{c}}$ \\
$0,8 \%$ & $2.40^{\mathrm{bc}}$ & $2.70^{\mathrm{b}}$ \\
$1,2 \%$ & $3.10^{\mathrm{ab}}$ & $4.05^{\mathrm{a}}$ \\
\hline
\end{tabular}

Ket : $\quad$ Angka yang diikuti oleh kode huruf yang berbeda menunjukkan adanya perbedaan yang nyata pada taraf signifikansi 5\%, (pada kolom yang sama) Ket Skala : 1= sangat enak; $2=$ enak; 3 = netral; 4 = tidak enak; 5 = sangat tidak enak (pada kolom yang sama)

Panelis menilai bahwa rasa kerupuk talas yang paling disukai adalah dengan bahan dasar tepung talas $150 \mathrm{gr}+$ tapioka 50 gr, konsentrasi $0,4 \%$ yaitu sebesar 1,75 dengat kategori enak. Hasil pengujian organoleptik menunjukkan bahwa rasa kerupuk talas yang memiliki nilai tertinggi adalah 4,05 dengan penilaian sangat tidak enak.

Menurut Kartika, dkk (1988) Pengaruh antara satu macam rasa dengan rasa yang lainnya tergantung pada konsentrasinya yaitu konsentrasi natrium bikarbonat yang semakin besar konsentrasinya sehingga rasa yang dominan pada kerupuk talas adalah rasa agak pahit yang dapat menghilangkan rasa yang lainnya.

\section{Organoleptik Kerenyahan Kerupuk} Talas

Hasil analisis uji organoleptik kerenyahan kerupuk talas dengan perlakuan bahan baku tepung talas dan tepung tapioka dengan konsentrasi
Natrium bikarbonat sebanyak $0,4 \%, 0,8 \%$ dan 1,2\% ditunjukkan dalam Tabel 6.

Kerenyahan kerupuk talas yang paling disukai adalah dengan bahan dasar tepung talas $150 \mathrm{gr}+$ tapioka $50 \mathrm{gr}$, konsentrasi 1,2\% yaitu sebesar 1,25 dengat kategori sangat renyah. Semakin banyak penambahan tepung tapioka pada pengolahan kerupuk talas akan menjadikan teksturnya lebih keras, sehingga dengan sedikit penambahan tepung tapioka kerenyahannya akan lebih terasa dan lebih di sukai. Kerenyahan suatu produk makanan karena adanya gelatinisasi.

Menurut Winarno (2002), gelatinisasi adalah fenomena gel dan diawali dengan pembengkakan granula pati akibat penyerapan air. Bila pati mentah di masukkan dalam air granula pati akan menyerap air dan mulai bengkak namun terbatas, sekitar $30 \%$ dari berat tepung. Proses pemanasan adonan tepung akan menyebabkan granula semakin membengkak karena penyerapan air semakin banyak. 
Tabel 6. Rerata Nilai Tingkat Kesukaan Kerenyahan Kerupuk Talas

\begin{tabular}{ccc}
\hline Perlakuan & \multicolumn{2}{c}{ Perlakuan Bahan Dasar } \\
\cline { 2 - 3 } Konsentrasi & $\begin{array}{c}\text { Tepung Talas 150 gr }+ \\
\text { Natrium }\end{array}$ & $\begin{array}{c}\text { Tepung Talas 50 gr }+ \\
\text { Tapioka 150 gr } \\
\text { Karbonat }\end{array}$ \\
\hline $0,4 \%$ & $2,15^{\mathrm{a}}$ & \\
$0,8 \%$ & $2,10^{\mathrm{a}}$ & $2,30^{\mathrm{a}}$ \\
$1,2 \%$ & $1,25^{\mathrm{a}}$ & $2,10^{\mathrm{a}}$ \\
\hline
\end{tabular}

Ket : $\quad$ Angka yang diikuti oleh kode huruf yang berbeda menunjukkan adanya perbedaan yang nyata pada taraf signifikansi 5\%, (pada kolom yang sama) Ket Skala : 1= sangat renyah; 2 $=$ renyah; $3=$ netral; $4=$ tidak renyah; $5=$ sangat tidak renyah (pada kolom yang sama)

Pengembangan granula pati juga disebabkan masuknya air kedalam granula dan terperangkap pada susunan molekulmolekul penyusun pati, sehingga suatu produk dal hal ini kerupuk talas akan semakin terasa kerenyahannya.

\section{KESIMPULAN}

Umbi talas mempunyai potensi yang tinggi untuk diolah menjadi produk pangan, khususnya kerupuk. Perlakuan komposisi bahan dasar dan konsentrasi $\mathrm{NaHCO}_{3}$ berpengaruh nyata terhadap sifat fisik, kimia dan organoleptik kerupuk talas.

\section{DAFTAR PUSTAKA}

Edward, S. 1997. Ilmu Pengetahuan Bahan Pangan. Institut Pertanian Bogor. Bogor

Lavlinesia. 1995. Kajian Beberapa Faktor Pengembangan Volumetrik dan Kerenyahan Kerupuk Ikan (tesis). Bogor : Program Pasca Sarjana. Institut Pertanian Bogor. Bogor.

Kartika Bambang, Pudji Hastuti, dan Wahyu Supartono. 1988. Pedoman
Uji Inderawi Bahan Pangan. PAU Pangan dan Gizi. UGM. Yogyakarta. Marliyati, S.A., dkk. 1992. Pengolahan Pangan Tingkat Rumah Tangga. IPB. Bogor.

Murdijati Gardjito, Theresia Fitria Kartika Sari dan, 2005, Pengaruh Penambahan Asam Sitrat Dalam Pembuatan Manisan Kering Labu Kuning (Cucurbita Maxima) Terhadap Sifat-Sifat Produknya, Jurnal Teknologi Pertanian1(2): 8185.

Virgit, A. 2004. Pengaruh Berbagai Formulasi Bahan Terhadap Karakteristik Kerupuk Sari Udang. Skripsi. Program Studi Teknologi Hasil Pertanian Jurusan Teknologi Pertanian Fakultas Pertanian. Universitas Sriwijaya.

Widowati, 2005. Ekstraksi dan Karakteristik Sifat Fisikokimia Varietas Talas. Prosedur Seminar Nasional. Teknologi Pangan. Patpi Denpasar. Bali.

Wijaya, H. 2002. Pembuatan Kerupuk Ikan. Majalah Sedap no. 5III2002 Jurusan Teknologi Pangan dan Gisi akultas Teknologi Pertanian. Institut Pertanian Bogor. Bogor.

Winarno. 2002. Kimia Pangan dan Gisi. PT Gramedia Pustaka Utama. Jakarta. 